\title{
Covid-19 Salgınının Peacock-Wiseman Sıçrama Tezi Çerçevesinde Değerlendirilmesi
}

\author{
DOI: $10.26466 /$ opus.881833
}

*

\author{
Osman Geyik * \\ * Arş. Gör. Dr., Dicle Üniversitesi /İ.̇.B.F/Maliye Bölümü, Diyarbakır/ Türkiye \\ E-Posta: osmangeyik@gmail.com \\ ORCID: 0000-0001-9885-9638
}

\section{Öz}

Kamu harcamaları devletin ekonomideki rolüne paralel olarak sürekli artış göstermektedir. Bu durum devletleri yeni finansman arayışına yöneltmektedir. Kamu hizmetlerinin finansman için erişilmesi en kolay olan ve genellikle başvurulan kamu kaynağı ise vergilerdir. Vergilerin elde edilmesi bakımından kolay olması, bu kaynaklara sıkça başvurulmasına neden olurken, bazı dönemlerde bu finans kaynağından efektif olarak faydalanmak mümkün değildir. Çünkü; söz konusu dönemlerde kamu harcamalarında tahmin edilemeyen düzeyde artışlar yaşanırken, kamu gelirlerinde aynı oranda artışlar meydana gelmemektedir. Kamu harcamalarının artışını açıklamada kullanılan teoriler yardımıyla bu artışların nedenleri açıklanmaya çalışılsa da bazı durumlarda bu teoriler konuyu açıklamada tek başına yeterli olmamaktadır. Kamu harcamalarındaki artışı açıklayan teorilerden biri olan Peacock-Wiseman sıçrama tezi, kamu harcamalarının artışı konusunda ele alınması ve incelemesi gereken teorilerin başında gelmektedir. Koronavirüs (Covid-19) salgın dolayısıyla devletin yerine getirmekle yükümlü olduğu bazı kamusal mal ve hizmet sunumlarında meydana gelen artış, bu konunun sıçrama tezi kapsamında ele alınması gerekliliğini ortaya çıkarmıştır. Çalışmada, kamu harcamalarının genel teorik çerçevesi çizildikten sonra Covid-19 salgını dolayısıyla meydana gelen artış Peacock -Wiseman sıçrama tezi kapsamında ele alınarak, salgin döneminde kamu harcamalarında ve gelirlerinde meydana gelen değişim üzerinde durulmuştur.

Anahtar Kelimeler: Kamu harcamaları , Covid-19 , Peacock-Wiseman Sıçrama Tezi 


\title{
Evaluation of Covid-19 Outbreak within the Framework of Peacock-Wiseman's Displacement Thesis
}

\begin{abstract}
Public expenditures are constantly increasing in parallel with the role of the state in the economy. This situation forces states to seek new financing.For the financing of public services, taxes are the public resource that is generally used and the easiest to access. Since taxes are easy to obtain, these resources are frequently used, and in some periods it is not possible to benefit from this financial resource effectively. This is because, during the periods in question, while there was an unpredictable increase in public expenditures, public revenues don't increase at the same rate. Although the reasons for these increases are tried to be explained with the help of the theories used to explain the increase in public expenditures, in some cases these theories alone are not sufficient to explain the issue. The Peacock-Wiseman's displacement thesis, which is one of the theories explaining the increase in public expenditures, is one of the leading theories that need to be addressed and analyzed about the increase of public expenditures. Due to the coronavirus (Covid-19) outbreak, the increase in the provision of some public goods and services that the state is obliged to fulfill has revealed the necessity of addressing this issue in the displacement thesis. After drawing the general theoretical framework of public expenditures in the study, the increase occurred due to the Covid-19 outbreak was considered within the scope of the Peacock-Wiseman's displacement thesis and the increase in public expenditures and revenues during the outbreak period was emphasized.
\end{abstract}

Keywords: Public Expenditures, Covid-19, Peacock-Wiseman's Displacement Thesis 


\section{Giriş}

Sosyal ve ekonomik açıdan olumsuz etkileri oldukça yüksek düzeyde olan Covid-19, Aralık 2019' dan bu yana tüm dünyada huzla yayılım göstermektedir. IMF (2020) tarafından yayınlanan raporda, Covid-19 salgınının yalnızca dünya çapında bir halk sağ lığı acil durumunu temsil etmekle kalmayıp, aynı zamanda kamu maliyesi üzerindeki olumsuz etkisiyle uluslararası ekonomik acil duruma da dönüş̧ü̆üü ifade edilmektedir. Covid-19'un mevsimsel gripten daha ölümcül ve SARS'tan en az on kat daha bulaşıcı olduğu belirtilmektedir. Bu nedenle hem gelişmiş hem de gelişmekte olan ülkelerde insanların sağllğına zarar verme potansiyeli çok yüksek düzeydedir (Wilder-Smith ve diğ.,2020; WHO, 2020a). Türkiye'de de ilk vakaların benzer tarihlerde görüldüğü dönemde, Dünya Sağlık Örgütü (WHO) tarafından 11 Mart 2020'de küresel salgın ilan edilmiştir (WHO, 2020b). Covid-19'un halk sağlığı sorunu olmasının yanı sıra ekonomik etkilerinin de varlığı bu salgının kamu otoriteleri tarafından çok yönlü önlemlerle ele alınmasını gerekli kılmıştır. Covid-19 hem insan sağlığını hem de sağlık sistemini tahrip eden bir salgın olduğu için ekonomik sistemi de tehdit eden bir yapıya sahiptir (Öztürk, 2020). Küreselleşme dolayısıyla artan mobilite insanların bu hastalığı daha hızı bir şekilde yaymasına ve salgının kontrolünün güçleşmesine neden olmuştur. Virüsün ortaya çıkmasından itibaren kamu otoriteleri tarafından alınan önlemlerin ekonomik etkilerinin bu süre zarfında tespit edilmesi pek mümkün değildir. Ancak; uzun süreli yasaklar dolayısıyla ekonomik faaliyetlerini kısıtlamak ya da durdurmak zorunda kalan işletmelerin belirli süre sonunda işletmelerini kapatması ve işçi çıkarması bu etkilerin kısa vadede görünen kısmını ifade etmektedir.

Salgın döneminde azalan ekonomik faaliyetler dolayısıyla kamu gelirlerinde de azalmaların meydana geldiğini ifade etmek mümkündür. Kafe, restoran, havayolu taşımacıllğı, konaklama gibi sektörlerin faaliyetlerinin zorunlu olarak kısıtlanması ve yasaklanması bu sektör faaliyetlerinden elde edilecek vergi gelirlerinin ve tüketim zinciri esnasında ortaya çıkacak gelirlerin azalmasına neden olmuştur. Bunun yanı sıra hizmet sektöründe faaliyette bulunan vatandaşlara devlet tarafından yapılan mali destekler (transferler) dolayısıyla da kamu gelirlerine duyulan ihtiyaç daha da artmıştır. Bu sorunu ortadan kaldırmak için para basma yolunu tercih eden hükümetlerin bu hamlelerle mali disiplinden uzaklaştı̆̆ gözlemlenmiştir. 
Covid-19 salgınının bir yılı aşan süre içerisinde mutasyona uğraması ve yayılımının artma tehlikesi, ekonomik ve sosyal sorunların daha uzun süreceği konusunda vatandaşları ve devletleri endişelendirmektedir. Ancak; aşı çalışmalarının hızlanması ve aşılamanın öncelikli gruplar üzerinden uygulanmaya başlanması salgın konusunda iyimser bir tablonun oluşmasını sağlamaktadır. Salgın döneminde en fazla artan harcama grubu sağlık harcamaları ve sosyal transferlerdir. Artan vakalar dolayısıyla yeni hastanelere duyulan ihtiyaç, kapasite artırımları, yeni cihaz alımları, ek personel ihtiyacı, ilaç giderleri ve son olarak aşılama maliyetleri, salgın sürecinde kamu harcamalarında meydana gelen artışların temel nedenleri içerisinde yer almaktadır. Artan harcamaların finansmanı için bu dönemde bazı yeni vergilerin getirildiği ve bazı vergilerde de yüksek oranda artışların yapıldığı sonucuna ulaşımıştır. Çalışmada, bu durumun kamu harcama teorileriyle uyumlu olup olmadığ sorusu üzerinde durulmuştur. Kamu harcama teorilerine ilişkin genel değerlendirmeler yapılarak, Covid-19 salgını döneminde kamu gelirlerinin ve harcamalarının seyri Peacock-Wiseman sıçrama tezi çerçevesinde incelenmiştir.

\section{Kamu Harcamalarına Kavramsal Bakış}

Kamu harcamalarını devletin yerel ve ulusal harcamaları olarak tanımlamak mümkündür. Devletin topladığ 1 vergiler ve sağladığ diğer kaynaklarla bütçe dengesini gözeterek yapmış olduğu harcamaların tamamı kamu harcamalarını ifade etmektedir (Bulutoğlu, 2004, s. 195). Kamu harcamalarının tanımını yaparken dar ve geniş anlamda kamu harcamaları ayrımını yapmakta yarar vardır. Dar anlamda kamu harcamasında, kamu harcamasını yapan kurumun hukuki niteliğine dikkat edilirken, geniş anlamda kamu harcamasında devletin toplumsal yaşam ve ekonomik faaliyetlerde üstlendiği rol ve yetki dikkate alınır (Yılmaz, 2016, s. 50).

Kamu kesimi , kolektif ihtiyaçları karşılamak maksadıyla tam kamusal malları ve yeterli düzeyde üretilmek üzere kamusal faydası yüksek yarı kamusal mal ve hizmetleri üretmektedir (Akgül Yılmaz, 2019, s. 99). Kamu kesiminin ekonomi içerisindeki büyüklüğünü ölçmede kullanılan önemli bir gösterge kamu harcamalarının miktarıdır. Kamu harcamalarının GSYH içerisindeki payı kamu kesiminin büyüklügüüü ifade etmektedir. Kamu harca- 
malarıla kamu kesimi kamusal mal ve hizmetleri sunmaktadır. Kamu hizmetlerini sunmak için bazı maliyetlerin ortaya çıkması söz konusudur ve bu maliyetler kamu harcamaları adıyla tanımlanmaktadır (Brown ve Jackson, 1994). 1929 ekonomik buhranının ardından devam eden ve 2 . Dünya savaşında hız kazanarak günümüzde de artış gösteren devletin ekonomideki payı, aynı minvalde kamu harcamalarında da artışı meydana gelmesine neden olmuştur. Devletin ekonomideki payının artmasının bazı sorunlara neden olacağını savunan görüşlerde; devletin büyüdükçe kendi ağırlı̆̆ altında ezilen Leviathan'a dönüşeceği ifade edilmiştir (Gauthier ,1969). J.J. Rousesseaus ise devletin kamu ekonomisi içerisinde payı arttıç̧a yönetimsel sorunların yaşanacağını ve rüşvetin artacağını savunmuştur ( Şener, 1998,s.30).

\section{Kamu Harcama Teorileri}

1929 ekonomik buhranın ardından ekonomik anlamda devlet anlayışında meydana gelen değişim neticesinde gelişmiş ülkelerde kamu harcamalarında hızlı artışlar meydana gelmiştir. Bu durum kamunun kaynak bulmasında güçlük yaşamasına ve mali disiplinin bozulmasına neden olmuştur (Köstekçi ve Yıldız, 2019, s. 75). Kamu harcamaları teorilerinde, kamu harcamalarının artış nedenleri ve bu artışın telafi edilmesi için uygulanacak kamu politikaları üzerinde durulmaktadır. Kamu harcamaları konusunda iktisat okullarının konuya bakışlarında önemli farklılıklar gözlemlenmektedir. İktisadi görüşlerin bir kısmında, devletin ekonomik büyümeyi sağlamak için harcamalar yapması gerekli görülürken, artan harcamalar dolayısıyla ortaya çıkacak olan kamu finansman açı̆̆ının vergiler yoluyla giderebileceği savunulmaktadır. Bu yaklaşım daha çok Keynesyen iktisadi görüşü savunanlar için geçerlidir. Klasik iktisatçılara göre ise durum daha farklıdır. Klasik iktisatçılarda; devletin gelirlerini aşmaması ve kamu harcamalarının bütçe açığı verilerek karşılanmaması gerektiği fikri egemen olmaktadır.

Maliye literatüründe, kamu harcama teorileri yer almaktadır. Bu teorilerde kamu harcamalarındaki artış şu şekilde açılanmaktadır; Wagner yaklaşımı , devletin ekonomi içerisindeki faaliyetlerinin artmasıyla kamu kesiminin büyüyeceğini ifade etmektedir. Sanayileşme, teknolojinin gelişmesi ve kentleşmenin yoğunlaşması gibi durumların ardından devletin ekonomi içerisindeki payının artacağını, bu nedenle kamu harcamalarında artışın olacağını ifade etmektedir (Savaşan, 2015, s. 42). Sanayi işletmelerinin artışı bu iş- 
letmelerin denetimini güçleştirmekte ve daha fazla kaynak artırılmasını gerekli kılmaktadır. Denetimi olanaksız hale gelen işletmelerin ise devlet tarafından devralınması, kamu kesiminin ekonomi içerisindeki payının artmasına neden olmaktadır (Bulutoğlu, 2004, s. 197). Peacock-Wiseman sıçrama tezinde, savaş, doğal afet gibi olağanüstü durumlar neticesinde kamu harcamalarında artışın olacağı savunulmaktadır. Rostow ve Musgrave'nin kalkınmacı yaklaşımında devletin 5 aşamalı kalkınma süreci içerisinde olduğu kabul edilmekte ve bu aşamalar için kamu harcamalarına ihtiyaç duyulmaktadır. Bu yaklaşıma göre süreç; geleneksel toplum, kalkışa geçiş aşaması, kalkış aşaması, olgunluk aşaması ve kitlesel tüketim aşamasından oluşmaktadır (Brown ve Jackson, 1994, s. 118). Baumol yaklaşımında ise; kamu sektörünün hizmet üretimindeki girdi maliyetlerinin artması kamu harcamalarında artışa neden olmaktadır. Kamu kesiminin verimli olmayan alanlara yatırım yapması ya da teknolojik gelişimlerin yeterli düzeyde takip edilememesi kamu harcamalarının artısına neden olacaktır. Ayrıca bürokrat davranışları, vergileme sürecinde yaşanan güçlükler, hükümetlerin siyasi çıarlarına göre hareket etmeleri ve politikacıların fayda maksimizasyonları da kamu harcamalarının artmasına neden olmaktadır (Savaşan, 2015, s. 50). Literatürde kamu harcamalarının artışını inceleyen, kamu harcamaları ve gelirlerinde yaşanan artş̧ların olağanüstü durumlarla ilişkili olduğunu ve mevcut duruma göre aşağı ya da yukarı yönlü hareket ettiğini açıklayan ampirik çalışmalar mevcuttur (Peacock ve Wiseman ,1979; Bohn, 1991 ; Garcia ve Henin, 1999; Hoover ve Sheffrin ,1992; Gounder ve diğerleri, 2007).

\section{Peacock- Wiseman Sıçrama Tezinin Kapsamı}

Peacock-Wiseman tarafından yapılan çalışmada, kamu harcamalarında bazı olağanüstü durumlarda artış yaşanacağ ifade edilmiştir. Bu dönemde devletlerin kamu harcamaların artırma yönünde kararlar almak istediklerini, vatandaşların ise vergi artş̧ları karşısında gönülsüz olacağı önermesi kapsamında, İngiltere'de 1890-1955 yılları arasındaki kamu harcamalarının gelişimi analiz edilmiştir. Peacock- Wiseman, kamu harcamaları ve kamu gelirleri arasında organik bir bağın olduğunu bu nedenle olağanüstü dönemlerde kamu harcamalarında ve vergilerde sıçramalı olarak bir artışın olacağını öne sürmüşlerdir. Peacock-Wiseman, olağanüstü dönemleri değerlendirme etkisi 
denilen bir etkinin varlığıyla açıklamaya çalışmışlardır. Buna göre; vatandaşlar yeni olağanüstü durum dolayısıyla daha fazla kamu harcamasına ihtiyaç duyduklarının farkına varmalarının ardından, daha fazla vergi yüküne katlanacaklarını ifade etmektedir. Ancak; olağanüstü şartların ortadan kalkmasının ardından vatandaşlar alıştıkları kamu harcama düzeyinin azalmasından yana olmayacakları için kamu harcamalarının miktarı eski seviyesinde devam etmeyecektir. Bu nedenden dolayı ne kamu harcama düzeyi ne de vergi yükü olağanüstü dönem öncesine dönmeyecektir (Peacock ve Wiseman, 1961). Bu artıs dolayısıyla vergilerin artırılması da gerekli olmakta, dolayısıyla vergilerin kamu harcamalarının içerisindeki payında da artışlar meydana gelmektedir (Kirmanoğlu, 2011, s. 55). 1890-1955 yılları arasında kamu harcamalarını seyrinin incelenmesi sonucunda ileri sürülen PeacockWiseman sıçrama tezinde kamu harcamalarıyla kamu gelirleri arasında doğrudan bir ilişkinin olduğu savunulmaktadır. Bu teze göre savaş, sosyal bunalımlar ve ekonomik krizler döneminde kamu harcamalarında bir artış gerçekleşmektedir. Ancak bu dönemler sona erdiğinde kamu harcamaları ve kamu gelirlerinde meydana gelen durum devam etmektedir. Bu dönemlerde vatandaşların artan vergi oranlarına karşı göstermiş oldukları tutum ve davranışlar farklılık göstermekte ve vergiye karşı direnç normal döneme göre daha az olmaktadır. Sıçrama tezine göre; sorunların olduğu dönemde artan kamu harcamaları, normalleşme sonrası eski seviyelerinde durur (Akgül Yılmaz, 2019, s. 108). Normal dönemlerde vatandaşlar vergi artışlarından memnun olmamaktadır. Ancak; olağanüstü dönemlerde mevcut durumun ortadan kalkacağına olan inançları gereği, vatandaşlar artan vergi oranlarına karşı daha anlayışlı ve uyumlu davranmaktadırlar. 


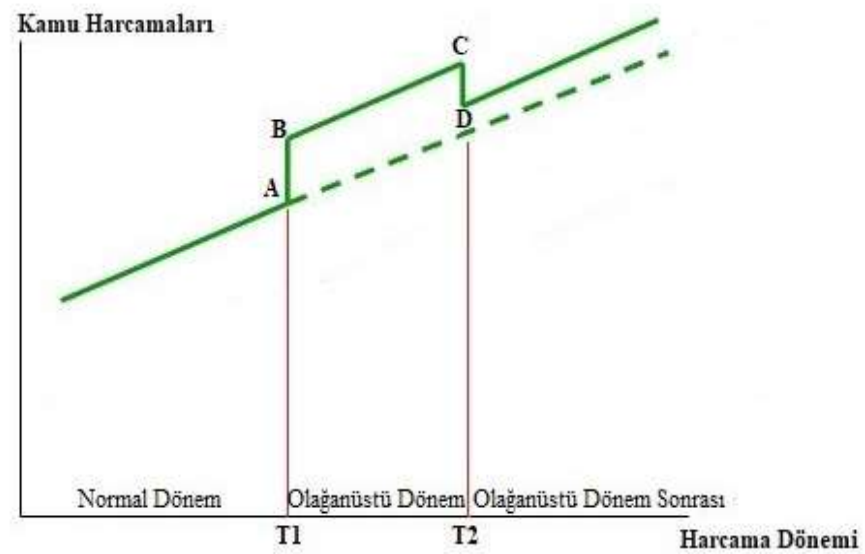

Şekil 1. Kamu Harcamalarındaki Sıçrama (Peacock-Wiseman 1961) sıçrama tezine dayanarak hazırlanmıştır.

Şekil 1 'de , kamu harcamalarının olağanüstü dönemlerde artış gösterdiği ifade edilmektedir. Kamu harcama miktarı normal dönemde A noktasındayken olağanüstü durumun meydana gelmesinin ardından aniden $B$ seviyesine sıçrama göstermektedir. Olağanüstü dönemin devam ettiği süre zarfında $C$ noktasına ulaşan kamu harcamaları, olağanüstü dönemin sona ermesinin ardından yeniden A noktası seviyesine gelmeyerek D noktası seviyelerinde devam etmektedir. Harcamalarda azalma olsa da bu azalış önceki artışa nispeten kısıtlı olmaktadır. Bu durum sıçrama tezinin temelini oluşturmaktadır. Konu Covid-19 kapsamında değerlendirilecek olursa; salgın sonrası kamu sağlık harcamalarında azalma meydana gelse de bu harcamaların salgın öncesi döneme ulaşması beklenmemektedir. Bunun en temel nedeni, salgın döneminde yapılan hastaneler ve kamuda istihdam edilmek için alınan sağlık personellerinin salgının sonra ermesinin ardından aynı şekilde sağlık harcamaları içerisinde yer alacak olmasıdır. Bu durum, kamu harcamalarının eski seviyesine gelmeyeceğinin basit bir örneğidir. Dolayısıyla bu dönemde artan kamu harcamalarının finansmanı için devreye sokulacak yeni vergilerin olağanüstü dönemin sona ermesinin ardından devam etmesi söz konusu olacaktrr. Türkiye'de, Marmara depreminden sonra 26.11.1999 tarihinde kabul edilen 4481 sayılı Yasa' da “31.12.2003 tarihine kadar uygulanmak üzere her nevi 
cep telefonu işletmecileri tarafından verilen (ön ödemeli kart satışları dahil) tesis, devir, nakil ve haberleşme hizmetleri (17.8.1999 ve 12.11.1999 tarihlerinde meydana gelen deprem nedeniyle mücbir sebep hali ilan edilen yerlerde, mücbir sebebin devam ettiği sürece abonelere verilecek ön ödemeli kart satışları dışındaki hizmetler hariç) \%25 oranında özel iletişim vergisine tabidir (ÖİV)" ibaresi yer almıştır. Deprem vergisi olarak bilinen ÖİV, depremin üzerinden yıllar geçmesine rağmen halen günümüzde de vatandaşlardan alınmaya devam edilmektedir. ÖIV bu durumda Peacock-Wiseman sıçrama tezinde belirtilen duruma verilebilecek bir örnektir.

\section{Covid-19 Salgınının Ekonomik Etkileri ve Alınan Önlemler}

Covid-19, insan sağlığına vermiş olduğu zararın yanı sıra ekonomik yönden de oldukça büyük riskler ve sorunlar içeren bir hale gelmiştir. Covid-19 salgını, daha önce meydana gelen salgınlardan oldukça farklı bir niteliğe sahiptir (Atkeson ,2020). Bu salgının son yüzyılda insan sağlığını tehlike altına alan en büyük salgın olduğu ve salgının ekonomik etkilerinin 1929 buhranından daha yıkıcı olabileceği görüşleri dile getirilmektedir. Covid-19'un büyük etkisi 2008-2009 küresel mali krizini aşmıştır. Bu krizin küresel bir durgunluğa yol açması söz konusudur (Anderson ve diğ. 2020; Goldman, 2020). Ancak; salgının ekonomik etkileri üzerine tam bir değerlendirme yapmak için henüz erkendir. Salgının özellikle sağlık harcamaları üzerinde yarattığı etki ve artan kamu sağlık harcamaları dolayısıyla ülkelerin bütçelerinde önemli açıkların meydana gelmesi ve mali disiplinin bozulması söz konusu olacaktır. Salgın dolayısıyla özellikle üretimde meydana gelen yavaşlama, ülke ekonomilerinde yıkıcı etkilerin ortaya çıkmasına neden olmaktadır. Tedarik zincirinde meydana gelen bozulmalar da bu etkilerin hissedilmesindeki diğer nedenler arasında yer almaktadır. Virüsün ortaya çıktığ 1 Çin'in, küresel tedarik zinciri içerisinde oldukça önemli bir yere sahip olması bu salgının ekonomik etkilerinin daha fazla hissedilmesine neden olmaktadır (Akbaş Akdoğan , 2020).

Günümüz dünya ülkelerinde sağllk harcamalarını kontrol altında tutmak devletlerin görevleri arasındadır (Demir ve Geyik, 2019). Bu hizmetlerin sağlanmasında ve yürütülmesinde insan sermayesinin yeri ve önemi oldukça büyüktür (Altunakar, 2019). Salgın neticesinde artan sağlık harcamalarının finansmanının kamu kaynaklarıyla karşılanması yeni kaynaklara ihtiyaç du- 
yulmasına neden olmuştur. Öncelikli olarak hastane kapasitelerinin artırılması ve yeni hastanelerin yapılması bu harcamaların başında gelmektedir. Ayrıca kamusal bir mal olması gereğiyle aşılama hizmetinin ücretsiz sunulması, sağlık harcamalarının artmasına neden olan bir diğer etkendir. Hastane sayısının ve yatak kapasitesinin artırılması, daha fazla sağllk personeline ihtiyaç duyulması ve virüsün tespiti için yapılan testlerin maliyetleri kamu harcamalarında artışa neden olurken; otel, restoran, havayolları gibi sektörlerin uzunca süre faaliyet gösterememesi ya da kısıtlı olarak faaliyetlerine devam etmesi hem bu sektörlerin hem de bu sektörde çalışan insanların gelir kaybına neden olmuştur. Bu gelir kayıpları dolayısıyla da vergi gelirlerinde de azalmalar meydana gelmiş ve kamu yeni finansman arayışına girmek zorunda kalmıştır. Devlet, bir taraftan vergi toplarken diğer taraftan kamu harcamalarını gerçekleştirmektedir. Bu dengenin bozulması kamu harcama sistemi üzerinde aksamaların yaşanmasına neden olmaktadır.

Salgın dolayısıyla ortaya çıkacak ekonomik sorunların başında ekonomik durgunluk gelmektedir. Bu süreçte ekonomilerin hızlı bir resesyon sürecine girmesi beklenmektedir. Salgının sona ermesinin ardından maliye politikaları yardımıyla ortaya çıkacak küresel krizin derinleşmesinin önüne geçilebilir. Ancak; ekonomik sorunların ele alınabilmesi için sağlık sorununun yani salgının ortadan kalkması gerekmektedir. Salgının mali etkisinin ölçülmesi şu an itibariyle güçtür ; ancak ekonomide meydana gelen durgunluk dolayısıyla ülke GSYH rakamlarında azalmaların hatta negatif büyümenin gerçekleşeceği ifade edilebilir. Vergi gelirlerindeki ve ekonomik faaliyetler neticesinde elde edilen katma değerlerin bu dönemde önemli düzeyde azalması, ödenen işsizlik maaşları, vergi indirimleri, kira yardımları vd., bunun yanı sıra kamu harcamalarında meydana gelen artış - sosyal harcamalar- bahsedilen durumun ortaya çıkmasına neden olmaktadır. Bununla birlikte özellikle gelişmekte olan ülkelerdeki kurların yükselmesi ve ulusal paranın değer kaybetmesi, birçok makroekonomik değişkeni olumsuz yönde etkilemektedir (Köse, 2020, s. 44).

Kamu idareleri tarafından yürütülen kamu politikalarının başında, Covid-19 salgınına yakalanan vatandaşların bu hastalıktan kurtulmalarını ve eski sağlıklarına kavuşmalarını sağlayacak sağlık hizmetlerini sunma konusu gelmektedir. Bu durum sağlık harcamalarının artmasına neden olmaktadır. 
Ancak; bu tür harcamalara ayrılan kaynağın artırılması, salgınla etkin mücadele için atılması gereken önemli adımların başında gelmektedir (Gaspar ve Mauro, 2020).

Salgın döneminde ulusal ve uluslararası kuruluşlar tarafından bazı önlemlerin alındığından söz etmek mümkündür. Uluslararası para fonu (IMF) tarafından; acil durum finansmanı, borç yardımı , borç erteleme çağrıları, likidite geliştirme ve mevcut kredi programlarının artırılması bu konuda sağlanan küresel nitelikteki desteklerden bazılarıdır (IMF, 2020). Türkiye de ise, kısa çalışma ödeneği ,asgari ücret desteği, Sosyal Güvenlik Kurumu prim ödemelerinde erteleme, vergi ödemesi ve beyanname verilmesinde erteleme, kredi-finansman desteği, ticari alacak sigortası desteği ve işyeri kira desteği, esnaf ve sanatkârların kredi borçları ödemelerinin ertelenmesi salgın döneminde sağlanan başlıca ulusal desteklerdendir (www.resmigazete.gov.tr).

\section{Covid-19 Salgını Döneminde Türkiye'de Kamu Gelirleri ve Harcamaları Üzerine Bir Değerlendirme}

Covid-19 'un devam etmesi ve kamunun finansmana duyduğu ihtiyacın artması bazı vergi kalemlerinde düzenleme yapılmasına neden olmuştur. $\mathrm{Bu}$ durum vergilerin fiskal ve ekstra fiskal amaçları çerçevesinde ele alındığında, bu dönemde yapılan bu müdahalelerin fiskal amaca yönelik olduğu söylenebilir. Salgınla bazı ürünlerden alınan vergilerin yüksek oranda artırılması, mevcut dönemde bu mal ve hizmetlere olan talebin artmasıyla ilişkili bir durum olarak değerlendirilebilir. Örneğin; oyun konsollarından alınan özel tüketim vergisinin (ÖTV) \%50 oranında artırılması bu konuya verilebilecek örneklerdendir. Konaklama vergisi ve dijital hizmet vergisi salgın dönemi içerisinde vatandaşların hayatına giren vergilerdir. Bunların yanı sıra Banka ve Sigorta Muameleleri Vergisi'nin ( BSMV) \%0,2' den \%1 e çıkarılması da yine bu dönemde artışı dikkat çeken bir vergi kalemidir. 19 Mayıs tarihli Cumhurbaşkanlığ Kararıyla 800'e yakın ithal ürüne \%2 - \%30 arasında değişen oranlarda ek gümrük vergisi getirilmesi, 01.02.2021 tarihli ve 4760 sayılı özel tüketim Vergisi (ÖTV) kanununa ekli elektrik motorlu araçlardan alınan vergi oranlarında artş̧a gidilmesi (Gelir İdaresi Başkanlığı, 2020), salgın döneminde artan kamu harcamalarının finansmanı için vergilere başvurulduğu sonucunu ortaya çıkarmaktadır. Bu durumun uzun vadede vergi gelirlerinde artışa $\mathrm{ml}$, ya da optimal vergilemeden sapma sorununa mı? Neden olacağ 
vergi gelirlerinde meydana gelen artsş ve tahakkuk/tahsil oranlaryyla tespit edilebilir.

Tablo 1' de kamu harcama büyüklüklerine ilişkin rakamlara yer verilmiştir. 2019-2020 dönemlerinde vergi gelirlerinin GSYH içerisindeki payında bir artışın meydana geleceği beklentisi içerisinde olunduğu görülmektedir. Ancak; salgın döneminde ekonomik faaliyetlerde meydana gelen yavaşlama dolayısıyla vergi gelirlerinde azalmanin meydana gelmesi beklenmektedir. $\mathrm{Bu}$ durum çalışmanın temelini oluşturan Peacock-Wiseman sıçrama teziyle ilişkili bir durumdur. Daha önce de bahsedildiği üzere, olağanüstü dönemlerde artan kamu harcamalarının finansmanını sağlamak için en kolay ulaşılabilecek kamu kaynağı olan vergilere başvurulmaktadır. Covid-19 salgınında da Türkiye ekonomisinde benzer bir durum yaşanmaktadır. Bu dönemde yeni vergiler hayata geçirilmiş ve bazı vergilerin oranında artış yoluna gidilmiştir. Vatandaşlar olağanüstü dönemlerde atılan bu adımlara daha zayıf direnç göstermekte ve vatandaşlık bilinciyle hareket edip bu tür felaketlerden kurtulmak için fedakârlık yapmaları gerektiğini düşünmektedirler. 
Tablo 1. Merkezi Yönetim Bütçe Büyüklükleri (Devlet Toplam Gelir ve Harcamalarının GSYH'ye Oranı) (Strateji ve Bütçe Başkanlığı, 2021)

\begin{tabular}{|c|c|c|c|c|c|c|c|}
\hline & 2015 & 2016 & 2017 & 2018 & 2019 & $2020(1)$ & $2021(2)$ \\
\hline Vergiler & 17,81 & 17,91 & 17,54 & 16,83 & 15,89 & 16,62 & 16,65 \\
\hline -Vasitasız & 5,06 & 5,26 & 5,24 & 5,89 & 5,67 & 5,57 & 5,37 \\
\hline -Vasitalı & 12,15 & 12,00 & 11,72 & 10,36 & 9,64 & 10,46 & 10,71 \\
\hline -Servet & 0,60 & 0,66 & 0,58 & 0,59 & 0,58 & 0,60 & 0,57 \\
\hline Vergi Dışı Normal Gelirler & 1,82 & 1,76 & 1,53 & 2,23 & 1,87 & 1,72 & 1,79 \\
\hline Faktör Gelirleri & 4,79 & 4,93 & 4,62 & 4,71 & 6,05 & 5,40 & 4,25 \\
\hline Sosyal Fonlar & 9,06 & 9,46 & 8,96 & 9,01 & 9,17 & 8,69 & 8,86 \\
\hline TOPLAM & 33,48 & 34,06 & 32,65 & 32,79 & 32,98 & 32,44 & 31,56 \\
\hline -Özelleştirme Gelirleri & 0,51 & 0,36 & 0,16 & 0,16 & 0,12 & 0,09 & 0,18 \\
\hline TOPLAM GELİR & 33,99 & 34,43 & 32,81 & 32,95 & 33,10 & 32,53 & 31,74 \\
\hline Cari Harcamalar & 15,21 & 16,24 & 15,32 & 15,82 & 16,50 & 17,74 & 15,98 \\
\hline Yatrrım Harcamaları & 3,45 & 3,48 & 3,67 & 3,77 & 2,67 & 2,63 & 2,64 \\
\hline -Sabit Sermaye & 3,45 & 3,47 & 3,66 & 3,75 & 2,63 & 2,62 & 2,62 \\
\hline -Stok Değişmesi & 0,00 & 0,01 & 0,01 & 0,02 & 0,03 & 0,01 & 0,01 \\
\hline Transfer Harcamaları & 15,43 & 16,09 & 15,65 & 15,73 & 16,98 & 18,21 & 17,66 \\
\hline -Cari Transferler & 14,44 & 15,22 & 14,88 & 15,01 & 16,16 & 17,52 & 16,96 \\
\hline -Sermaye Transferleri & 1,00 & 0,86 & 0,76 & 0,72 & 0,82 & 0,69 & 0,70 \\
\hline Stok Değişim Fonu & 0,00 & 0,00 & 0,00 & 0,00 & 0,00 & 0,00 & 0,00 \\
\hline TOPLAM HARCAMA & 34,09 & 35,81 & 34,64 & 35,31 & 36,14 & 38,59 & 36,28 \\
\hline BORÇLANMA GEREĞİ & 0,10 & 1,38 & 1,83 & 2,36 & 3,04 & 6,06 & 4,54 \\
\hline Faiz Dışı Harcama & 31,76 & 33,80 & 32,72 & 33,20 & 33,63 & 35,56 & 32,91 \\
\hline Faiz Ödemeleri & 2,33 & 2,01 & 1,92 & 2,11 & 2,51 & 3,03 & 3,37 \\
\hline Faiz Hariç Borçlanma Gereği & $-2,23$ & $-0,63$ & $-0,09$ & 0,25 & 0,53 & 3,03 & 1,17 \\
\hline Özelleştirme Gelirleri & 0,51 & 0,36 & 0,16 & 0,16 & 0,12 & 0,09 & 0,18 \\
\hline Özelleştirme Hariç Borçlanma Gereği & 0,61 & 1,74 & 1,99 & 2,52 & 3,16 & 6,15 & 4,72 \\
\hline Faiz ve Özelleştirme Hariç Borç. Ger. & $-1,72$ & $-0,27$ & 0,06 & 0,41 & 0,65 & 3,12 & 1,35 \\
\hline
\end{tabular}

(1): Gerçekleşme Tahmini

(2): Program 
Salgın döneminde ekonomik faaliyetlerde meydana gelen yavaşlamanın kamu gelirleri üzerinde olası etkileri kaçınılmazdır. Bu gelirler içerisinde en fazla kayba uğrayan gelir türünün başında vergiler gelmektedir. Tablo 1 'de yer alan merkezi yönetim bütçe büyüklükleri değerlendirildiğinde, vergi gelirlerinin bütçe içerisindeki payına ilişkin gerçekleşme tahminlerinde 2020 yılında vergi gelirlerinin GSYH'ye oranı \%16,62 olarak belirtilmiştir. Bu rakam 2019 yılında \%15,89 olarak gerçekleşmiştir. Salgının şiddetinin ve etkilerinin arttığ bu dönemde vergi gelirlerindeki artışın neden kaynaklandığı sorusu dikkat çekmektedir. Bu durum bazı vergi kalemlerinde vergi oranlarının artırılması ve yeni vergilerin uygulamaya konulmasıyla açıklanabilir. 2021 yılinda programlanan rakamlarda ise toplam vergi gelirlerinin 0,03 puan artacağ 1 yönünde bir değerlendirilmede bulunulmuştur. 2021 yılı içerisinde salgın sürecinin normale döneceği öngörüsüyle hazırlanan programda piyasa ekonomisinde yeniden yasakların gevşetilmesi ve faaliyetlerin kaldı̆̆ı yerden devam etmesi kamu gelirlerinde de artı̧ın yaşanmasına olanak sağlayacaktrr. Tablo 1' de yer alan vasitasiz vergilerde meydana gelmesi beklenen azalmanın ise 2018-2020 döneminde \% 22 oranında uygulanan kurumlar vergisi oranının 2021 yılından itibaren \% 20 oranında uygulanacak olmasından kaynaklandığı ifade edilebilir (Gelir İdaresi Başkanlığı ,2020). Ancak; salgının şiddetini artırarak devam etmesi ve kamu gelirlerine duyulan ihtiyaç dolayısıyla yeni düzenlemeler yapılmıştır. Bu çerçevede, Kurumlar Vergisi Kanununa geçici madde eklenmiştir. 21 Nisan 2021 tarihli 31462 sayılı Resmî Gazete 'de: “Geçici Madde 13 - (1) Bu Kanunun 32 nci maddesinin birinci fikrasında yer alan \%20 oranı, kurumların 2021 yılı vergilendirme dönemine ait kurum kazançları için \%25, 2022 yılı vergilendirme dönemine ait kurum kazançları için \%23 olarak uygulanır." Şeklinde bir karar yayımlanmıştır. Bu karar, yaşanan olağanüstü durumların vergi oranlarına yansıdığı ve vatandaşlar üzerinde vergi yükü oluşturduğu sonucunu ortaya çıkarmaktadır.

Tablo 1 'de dikkat çekilmesi gereken bir diğer konu ise transfer harcamalarına ilişkin rakamlardır. Salgın döneminde artan transfer harcamalarının 2021 yılında hayatın normal seyrine döneceği varsayımıla azalma eğiliminde olacağı düşünülmektedir. 2019 yılında GSYH'ye oranı \%16,98 olan transfer harcamalarının 2020'de \%18,21 olarak gerçekleşeceği tahmin edilmekte ve bu rakamın 2021 yılında \%17,66'ya gerileyeceği öngörülmektedir (Strateji ve Bütçe Başkanlığı, 2021). Tablo 1 'den de anlaşıldığı gibi salgının 
sosyal hayatı etkilemesinin yanı sıra ekonomik yönden de oldukça zarar verici boyutlarda olduğu ifade edilebilir. Bu durum salgınla mücadelede kamu politikalarının ve desteklerinin ne kadar önemli düzeyde olduğunun göstergesi olarak değerlendirilebilir.

Tablo 2. Sağhık Bakanlı̆̆ı Bütçesi (2019-2023 - Bin TL) (Kaynak: 2021 Bütçe Gerekçesi)

\begin{tabular}{llll}
\hline YIL & TL & YIL & Değişim Oranı (\%) \\
\hline $\mathbf{2 0 1 9}$ & 48.437 .276 & $\mathbf{2 0 1 8 - 2 0 1 9}$ & 28,92 \\
\hline $\mathbf{2 0 2 0}$ & 58.875 .829 & $\mathbf{2 0 1 9 - 2 0 2 0}$ & 21,55 \\
\hline $\mathbf{2 0 2 1}$ & 77.615 .519 & $\mathbf{2 0 2 0 - 2 0 2 1}$ & 31,8 \\
\hline $\mathbf{2 0 2 2}^{* *}$ & 85.113 .403 & $\mathbf{2 0 2 1 - 2 0 2 2}$ & 9,7 \\
\hline $\mathbf{2 0 2 3}^{* *}$ & 92.972 .943 & $\mathbf{2 0 2 2 - 2 0 2 3}$ & 9,2 \\
\hline
\end{tabular}

*Teklif Rakamı

**Tahmin Rakamları

Tablo 2' de 2019-2023 yıllarına ait Sağlık Bakanlığı bütçesine ve bütçedeki değişim oranına yer verilmiştir. Türkiye Büyük Millet Meclisi Plan ve Bütçe Görüşmeleri sonucunda Sağlık Bakanlığı merkezi yönetim bütçesi, 2021 yılı için \%31,8 artışla 77 milyar 615 milyon Türk lirası olarak belirlenmiştir. Bu rakam 2019 yılında 58 Milyar 875 milyon Türk lirası olarak gerçekleşmiştir. Bu denli bir artışın temel nedeni salgının beklenenden daha uzun sürmesi ve bu nedenle sağlık harcamalarında meydana gelen beklenmedik artıştır. Salgınla etkili mücadele amacıyla, 2021 yılı merkezi yönetim bütçesinde koruyucu sağlık hizmetleri için ayırılan kaynak 2020 yılına göre \%24,1 artırılarak 19 milyar TL'ye çıkarılmıştır. Sağlık çalışanlarının sayısı 1 milyon 100 bini aşmıştır (Sağlık Bakanlığ1 ,2020). Tablo 2 'den de anlaşılacağı gibi, sağlık harcamaları Covid-19 dolayısıyla yüksek oranda artış göstermiştir. 2022-2023 yıllarında salgının sona ereceği beklentisi dolayısıyla bu artış miktarının önceki yıllara göre sinırlı kalacağı tahmin edilmektedir. Ancak; daha önce de ifade edildiği gibi olağanüstü dönem sona erse dahi kamu harcamalarının eski seviyesine gelmesi söz konusu olmayacaktır.

\section{Sonuç ve Öneriler}

Covid-19 salgını, ekonomide yaşanan durgunluk dolayısıyla GSYH'de, vergi iadeleri ve ertelemeleri dolayısıyla da kamu gelirlerinde önemli oranda azalmaların meydana gelmesine neden olmuştur. Covid-19 salgınının ardından ortaya çıkan arz ve talep daralmaları, kamu politikalarının ve kaynaklarının 
gereksinimini daha fazla hissettirmektedir. Zorunlu olarak uygulanan kısitlamalar dolayısiyla piyasa ekonomisinde meydana gelen durgunluk kamu gelirlerinin azalmasına neden olurken, artan kamu harcamaları (transferler, sağlık harcamaları vb.) ise kamu kesiminin bu sorunlarla mücadele için daha fazla finansmana ihtiyaç duyması sorununu ortaya çıkarmıştır. Kriz dönemlerinde hane halkı gelirlerinde meydana gelen azalma, kamu gelirlerinde de dolaylı olarak azalmanın meydana gelmesine neden olmaktadır. Ancak; bu dönemlerde yine hane halkı artan vergilere karşı daha az direnç göstermekte ve kamunun uygulamış olduğu politikalara daha fazla uyum sağlamaktadır. Peacock- Wiseman sıçrama tezi bu konuyla ilişkili bir durumdur. Türkiye'de yaşanan deprem sonrası hayata geçirilen özel iletişim vergisi bu teze örnek bir vergidir. Sıçrama tezinde bahsedildiği gibi olağanüstü dönemlerde alınan vergiler bu durum sona erdikten sonra da devam etmektedir. Kafe, restoran, havacılık sektörü ve eğlence mekânlarının zorunlu olarak kapanmış olması, vergi gelirlerinde önemli oranda azalmaların meydana gelmesine neden olmuştur. Bu durumun yıkıcı etkisini ortadan kaldırmak için yeni vergilerin uygulamaya konulması ve bazı vergilerin oranlarında artş̧a gidilmesi kamu politikası olarak değerlendirilebilir ve vergi tazyiki açısından daha az tepkisel olacağ 1 ifade edilebilir.

Devletlerin salgınla mücadele döneminde, parasal genişleme yoluyla kaynak yaratma girişimlerinde bulunması uzun dönemde enflasyonist etkinin varlığı dolayısıyla kısıtlı olarak başvurulması gereken bir finansman kaynağı olarak değerlendirilmelidir. Uygulanan genişletici maliye politikaları yardımıyla vatandaşların kayıpları giderilmeye çalışılabilir ve bu amaçla destek paketleri oluşturulabilir. Ancak; bu tür bir yöntemin ekonomik istikrarı bozacağı konusu göz ardı edilmemelidir. Artan vergi oranları ve yeni vergilerle elde edilen gelirler bu dönemde geliri azalan hane halkı için gelir dağ llımında adaletin sağlanması amacıyla efektif bir şekilde kullanılmalıdır.

Sonuç olarak; bu dönemde ekonomi yönetimi tarafından uygulanacak maliye ve para politikalarının birbiriyle koordinasyon içerisinde olması, bu tür önlemlerin etkinliği ve uzun dönemde ortaya çıması muhtemel olan ekonomik krizlerin bertaraf edilmesi bakımından önem arz etmektedir. Kontrolsüz şekilde uygulanacak ekonomi politikalarının uzun vadedeki etkilerinin, salgın döneminden daha tahrip edici niteliğe dönüşmesi söz konusu olabilir. Bu nedenle uygulanacak kamu politikalarının vatandaşların 
daha iyi şartlarda yaşamalarını sağlayacak şekilde tasarlanması ve salgın döneminde yaşanan refah kayıplarını telafi edecek nitelikte olması gerekmektedir. Vergi oranlarındaki artış ve yeni vergiler neticesinde elde edilen gelirlerle hane halkının zararları tanzim edilmelidir. Ancak; bunu sağlarken diğer bir taraftan vatandaşların vergi yükü altında ezilmesinin önüne geçilmeli ve salgının sona ermesi durumunda vergi politikaları yeniden gözden geçirilmelidir. 


\title{
EXTENDED ABSTRACT
}

\section{Evaluation of Covid-19 Outbreak within the Framework of Peacock-Wiseman's Displacement Thesis}

\author{
Osman Geyik \\ Dicle University
}

The coronavirus epidemic (Covid-19), which has very high social and economic adverse effects, has been spreading rapidly all over the world since 2019. Covid-19 is an epidemic that destroys both human health and the health system, it has a structure that threatens the economic system. Increased mobility due to globalization has caused people to spread this disease faster and the control of the epidemic has become difficult. It is not possible to determine the economic effects of the measures taken by the public authorities since the emergence of the virus during this period. However, the companies that have to restrict or stop their economic activities due to prolonged prohibitions closing their businesses at the end of a certain period and laying workers represent the visible part of these effects in the short term. It is possible to state that there has been a decrease in public revenues due to the decreased economic activities during the epidemic period. Due to the financial support (transfers) provided by the state to citizens operating in the service sector, the need for public revenues has increased even more. It has been observed that governments that prefer to print money in order to eliminate this problem have moved away from fiscal discipline. It has been concluded that some new taxes were introduced in this period to finance the increased expenditures and high rates of increases were made in some taxes. In the study, the question of whether this situation is compatible with public expenditure theories is emphasized. By making general evaluations on public expenditure theories, the course of public revenues and expenditures during the Covid-19 outbreak was examined within the framework of the Peacock-Wiseman's displacement thesis.

In the study conducted by Peacock-Wiseman, it has stated that public expenditures will increase in some extraordinary situations. In this period, 
the development of public expenditures in England between the years 18901955 was analyzed within the scope of the proposition that states wanted to take decisions to increase public expenditures and citizens would be reluctant to tax increases. Peacock-Wiseman argued that there is an organic link between public expenditures and public revenues, so there will be a gradual increase in public expenditures and taxes during extraordinary periods. But; After the removal of extraordinary conditions, the amount of public expenditures will not continue at the previous level, as the citizens will not be in favor of decreasing the level of public expenditure they are used to. If the subject is evaluated within the scope of Covid-19; Although there is a decrease in public health expenditures after the epidemic, these expenditures are not expected to reach the pre-epidemic period. The main reason for this is that hospitals built during the epidemic period and healthcare personnel recruited for employment in the public sector will likewise be included in health expenditures after the outbreak. This is a simple example that public spending will not recover. Therefore, new taxes to be introduced to finance the increased public expenditures in this period will continue after the end of the extraordinary period.

The financing of health expenditures, which increased as a result of the epidemic, with public resources caused the need for new resources. First of all, increasing the hospital capacities and building new hospitals are the main expenditures. In addition, as it is a public good, providing vaccination services free of charge is another factor that causes an increase in health expenditures. While increasing the number of hospitals, increasing the bed capacity, needing more health personnel and the costs of the tests performed for the detection of the virus cause an increase in public expenditures; The fact that sectors such as hotels, restaurants and airlines couldn't operate for a long time or continued their activities in a limited way caused a loss of income for both these sectors and the people working in this sector. Due to these income losses, tax revenues also decreased and the public had to seek new financing. There is a point that should not be forgotten, while the state collects taxes, on the other hand, it realizes public expenditures. Disruption of this balance causes disruptions in the public expenditure system.

It reveals that taxes had applied to finance the increased public expenditures during the epidemic period. Does this result in an increase in tax revenues in the long run, or a problem of deviation from optimal taxation? It can 
be determined by the increase in tax revenues and the accrual / collection rates. The possible effects of the slowdown in economic activities on public revenues during the epidemic period are inevitable. Among these revenues, taxes are the leading type of income that suffers the most loss. Due to the stagnation in the market economy due to mandatory restrictions, a decrease in public revenues, increased public expenditures (transfers, health expenditures, etc.) It also causes an indirect decrease in public revenues. However, during these periods, households show less resistance to increasing taxes and more adapt to these policies implemented by the public.

As a result; the coordination of fiscal and monetary policies to be implemented by the economy management in this period is important in terms of the effectiveness of such measures and the elimination of economic crises that will arise in the long term. The long-term effects of uncontrolled economic policies may turn into more destructive than the epidemic period. For this reason, the public policies to be implemented must be designed in a way that enables citizens to live in better conditions and must be capable of compensating for the wealth losses experienced during the epidemic period. The losses of the household should be compensated with the income obtained as a result of the increase in tax rates and new taxes. But; While ensuring this, on the other hand, the oppression of citizens under the tax burden should be prevented and tax policies should be re-evaluated in case the epidemic ends.

\section{Kaynakça / References}

22.03.2020 tarih ve 31076 sayll RG, 3 No.lu Genel Tebliğ. ( Mart 22, 2020). Resmi Gazete. 28 Ocak 2021 tarihinde https://www.gib.gov.tr/node/143116 adresinden erişildi.

24.03.2020 tarihli 518 sayılı No.lu V.U.K. Genel Tebliği. (Mart 24, 2020). Resmi Gazete. 28 Ocak 2021 tarihinde https://www.gib.gov.tr/node/143134 adresinden erişildi.

25.03.2020 tarihli ve 7226 sayll Kanun. (Mart 26, 2020). Resmi Gazete. 28 Ocak 2021 tarihinde https://www.gib.gov.tr/sites/default/files/fileadmin/haberler/notlar/haberAciklayiciBilgiNotu27032020 1.pdf adresinden erişildi.

Akdoğan, D. A.(2020). COVID-19 ile mücadelede maliye politikası önlemleri. Anadolu Kongreleri 5. Uluslararası sosyal bilimler Kongresi 26-27 Aralık , Diyarbakır , Tam Metin Bildiri Kitab1 ,ISBN: 978-605-70159-8-3. 
Altunakar ,S. Ş. (2019). The relationship between health expenditures and economic growth: OECD countries (1980-2017). Çevik ,D.D. ve Geyik,O. Contemporary Issues Labor, Public Finance \& Administration ISBN: 978-1-912503-85-8 , IJOPEC Publication, London.

Anderson, R. M., Heesterbeek, H., Klinkenberg, D., ve Hollingsworth, T. D. (2020). How will country-based mitigation measures influence the course of the COVID-19 epidemic?. The Lancet, 395(10228), 931-934. DOI: https://doi.org/10.1016/S0140-6736(20)30567-5.

Atkeson, A. (2020). What will be the economic impact of covid-19 in the US? Rough estimates of disease scenarios (No. w26867). National Bureau of Economic Research. DOI: https://doi.org/10.3386/w26867.

Bazı alacakların yeniden yapılandırılması ile bazı kanunlarda değişiklik yapılması hakkında kanun. (17 Kasım 2020). Resmî Gazete. 10 Ocak 2021 tarihinde https://www.resmigazete.gov.tr/eskiler/2020/11/20201117-1.htm adresinden erişildi.

Bohn, H. (1991). Budget balance through revenue or spending adjustments?: Some historical evidence for the United States. Journal of monetary economics, 27(3), 333-359.

Brown, C. V. ve Jackson, P. M. (1990). Public sector economics (4th ed.). Oxford, UK: Blackwell.

Bulutoğlu, K. (2004). Kamu ekonomisine giriş. İstanbul: Batı Türkeli Yayıncllk.

Demir , M. ve Geyik, O. (2019).Evaluation of the impact of globalization on health expenditures in terms of public finance. Çevik ,D.D. ve Geyik,O. Contermporary Issues Labor, Public Finance \& Administration ISBN: 978-1-912503-85-8 , IJOPEC Publication, London..

Garcia, S. ve Hénin, P. Y. (1999). Balancing budget through tax increases or expenditure cuts: is it neutral?. Economic Modelling, 16(4), 591-612.

Gaspar, V. ve Mauro, P. (2020). Fiscal policies to protect people during the coronavirus outbreak. IMF Blog, 5 .

Gauthier, D. P. (1969). The logic of Leviathan: the moral and political theory of Thomas Hobbes. Oxford University Press.

Goldman,S.(2020). US Daily: A sudden stop for the US economy. 2 Mart 2021 tarihinde https://www.goldmansachs.com/insights/pages/us-daily-20-march2020.html adresinden erişildi. 
Gounder, N., Narayan, P. K. ve Prasad, A. (2007). An empirical investigation of the relationship between govemment revenueand expenditure. International Journal of Social Economics.

Hazine ve Maliye Bakanlığı. (2020). Aylk bütçe bülteni. 28 Ocak 2021 tarihinde https://ms.hmb.gov.tr/uploads/2021/01/2020 Aralik-Aylik-Butce-Bultenimin.pdf adresinden erişildi.

Hazine ve Maliye Bakanlığı. (2020). Gerçekleşme raporu. 25 Ocak 2021 tarihinde https://ms.hmb.gov.tr/uploads/2021/01/Butce-Gerceklesme-Raporu-Aralik-1.pdf adresinden erişildi.

Henrekson, M. (1993). Wagner's law-a spurious relationship? Public Finance, 48, 406415.

Hoover, K. D. ve Sheffrin, S. M. (1992). Causation, spending, and taxes: Sand in the sandbox or tax collector for the welfare state?. The American Economic Review, 225-248.

IMF (2020). IMF's Georgieva: COVID-19 economic outlook negative, but rebound in 2021. 5 Mart 2021 tarihinde https://www.imf.org/extemal/mme$\mathrm{dia} / \mathrm{view}$. aspx?vid=6144138845001 adresinden erişildi.

Kirmanoğlu, H. (2011). Kamu ekonomisianalizi. İstanbul: Beta Basım A.Ş.

Köse, Z. (2020). COVID-19'un küresel ekonomiye etkileri. Şen, E., Hıdıroğlu, D.,Yılmaz, O., COVID-19 Pandemisinde Yönetim ve Ekonomi , ISBN : 978-625-772732-7, Ankara: Gazi kitabevi.

Köstekçi, A. ve Yıldız,F. (2019).Kamu borç yönetimi Türkiye ve OECD ülke uygulamaları, Bursa: Ekin Yayınevi, ISBN: 978-605-327-905-1,

Orhan, Ş. (1998). Kamu ekonomisi. İstanbul: Alkım Yayınevi.

Öztürk, R. (2020). The trends of marketing literature during the COVID19 Pandemic: A review with bibliometric analysis. OPUS-International Journal of Society Researches, 16(Özel Say1), 3251-3273. DOI: 10.26466/opus.788120.

Peacock, A. T., ve Wiseman, J. (1979). Approaches to the analysis of government expenditure growth. Public Finance Quarterly, 7(1), 3-23.

Peacock, A. T., ve Wiseman, J. (1961). Front matter, the growth of public expenditure in the United Kingdom. In The growth of public expenditure in the United Kingdom (p.32-0). Princeton University Press.

PWC. (2020). Covid-19 kapsammda dünyada ve Türkiye'de alman vergi önlemleri. 28 Ocak 2021 tarihinde https://www.pwc.com.tr/tr/Hizmetlerimiz/vergi/covid-19kapsaminda-dunyada-ve-turkiyede-alinan-vergi-onlemleri.pdf adresinden erişildi. 
Sağlık Bakanlığı. (2020). Sağ̆lk Bakanlığı 2021 yılı bütçe teklifi. Ankara. 5 Mart 2021 tarihinde https://www.saglik.gov.tr/TR,76989/saglik-bakanligi-2021-butcesitbmm-plan-butce-komisyonunda-kabul-edildi.html adresinden erişildi.

Savaşan, F. (2015). Kamu ekonomisi. Bursa: Dora Basım-Yayın.

Strateji ve Bütçe Başkanlığı (2020). 2021 Bütçe Gerekçesi. 25 Ocak 2021 tarihinde https:/www.sbb.gov.tr/wp-content/uploads/2020/10/2021-butce gerekcesi 21-10-2020 WEB.pdf adresinden erişildi.

T.CStrateji Bütçe Başkanlığı. (t.y). Merkezi yönetim bütçe gerçekleşmeleri ve beklentiler raporu. 25 Ocak 2021 tarihinde https://www.sbb.gov.tr/butce-merkezi-yonetim-butce-gerceklesmeleri-ve-beklentiler-raporlari/ adresinden erişildi.

Wilder.S., A., Chiew,C. J., ve Lee, V. J. (2020). Can we contain the Covid-19 outbreak with the same measures as for SARS ? .The lancet infectious diseases. https://doi.org/10.1016/S1473-3099(20)30129-8.

World Health Organization (2020a). Timeline of WHO's response to COVID-19. 25 Ocak 2021 tarihindehttps:/www.who.int/news-room/detail/29-06-2020-covidtimeline adresinden erişildi.

World Health Organization (2020b). Coronavirus disease , 28 Ocak 2021 tarihinde https://www.who.int/en/ adresinden erişildi.

Yllmaz, G.A. (2019). Kamu maliyesi. İstanbul: Türkmen Kitabevi.

Yllmaz, B. E. (2016). Maliye. İstanbul: Der Yayınları.

\section{Kaynakça Bilgisi / Citation Information}

Geyik, O. (2021). Covid-19 salgınının Peacock-Wiseman sıçrama tezi çerçevesinde değerlendirilmesi. OPUS-Uluslararası Toplum Araştırmaları Dergisi, 17(Pandemi Özel Sayıs1), 3764-3786. DOI: 10.26466/opus.881833 